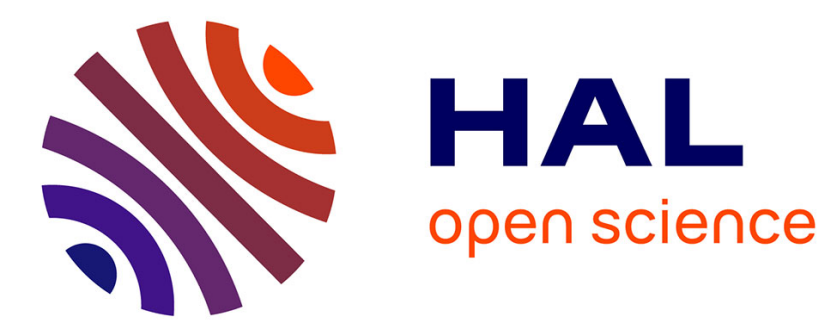

\title{
The Structure of the Legal system and the Emergence of the State
}

\author{
Michel Troper
}

\section{To cite this version:}

Michel Troper. The Structure of the Legal system and the Emergence of the State. 2021. halshs03280485

\section{HAL Id: halshs-03280485 \\ https://shs.hal.science/halshs-03280485}

Preprint submitted on 7 Jul 2021

HAL is a multi-disciplinary open access archive for the deposit and dissemination of scientific research documents, whether they are published or not. The documents may come from teaching and research institutions in France or abroad, or from public or private research centers.
L'archive ouverte pluridisciplinaire HAL, est destinée au dépôt et à la diffusion de documents scientifiques de niveau recherche, publiés ou non, émanant des établissements d'enseignement et de recherche français ou étrangers, des laboratoires publics ou privés. 


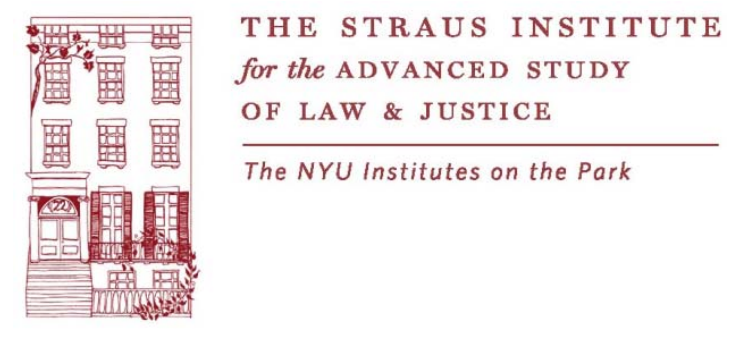

\title{
THE J OSEPH AND GWENDOLYN STRAUS INSTITUTE FOR THE ADVANCED STUDY OF LAW \&J USTICE
}

\author{
Professor J.H.H. Weiler \\ Director of The Straus Institute
}

Straus Working Paper 06/ 12

\author{
Michel Troper
}

The Structure of the Legal system and the Emergence of the State

NYU School of Law • New York, NY 10011

The Straus Institute Working Paper Series can be found at http:// nyustraus.org/ index.html 
All rights reserved.

No part of this paper may be reproduced in any form without permission of the author.

ISSN 2160-8261 (print)

ISSN 2160-827X (online)

Copy Editor: Danielle Leeds Kim

(C) Michel Troper 2012

New York University School of Law

New York, NY 10011

USA

Publications in the Series should be cited as: 


\title{
The Structure of the Legal system and the Emergence of the State
}

\author{
By Michel Troper*
}

\begin{abstract}
This essay is an attempt to use some of the concepts of legal theory to interpret the emergence of the modern state. Starting from Kelsen's and Weber's definition of the State, I argue that the modern State or Sate stricto sensu is a form of political power that is exercised in the form of law and justified with the use of concepts like sovereignty and I try to show that these concepts, that are constitutive of the State, emerge as the result of constraints arising from the hierarchy of norms and weighing on legal argumentation.
\end{abstract}

\footnotetext{
* This paper has been prepared in the ideal intellectual environment provided by the Straus Institute. I am extremely grateful for the stimulating help and comments from its director Joseph Weiler, other Fellows, friends and colleagues, particularly Ruth Gavison, Miriam Aziz, Francesco Di Donato, Riccardo Guastini, Janez Kranjc, Charles Leben, Frédéric Martin, Philip Hamburger and François Saint-Bonnet.
} 
$\begin{array}{lr}\text { I. Introduction } & 3\end{array}$

The problem of the origin of the State in the Middle Ages 8

II. The emergence of a hierarchy of norms 13

A. What is a hierarchy of norms ? 13

B. The absence of a hierarchy of norms in the Middle Ages 16

C. The emergence of a hierarchy of norms in the $16^{\text {th }}$ century 19

$\begin{array}{lr}\text { III. Sovereignty } & 29\end{array}$

A. The absence of sovereignty in the Middle Ages 33

B. Sovereignty in the modern age $\quad 35$

$\begin{array}{ll}\text { IV. The hierarchy of norms and sovereignty } & 37\end{array}$

$\begin{array}{ll}\text { V. Conclusion } & 41\end{array}$ 


\section{Introduction}

For the most part, legal theory, at least in the European tradition, is ahistorical. It aims at giving a general description of the structure of the legal system, the function of the law or the particularities of legal reasoning in general terms, a description that should be valid not for one particular legal system, but for all legal systems of all countries and all times. According to Kelsen it should even be valid not only for existing but also for every possible legal system. Legal theorists have therefore little curiosity in historical analysis.

On the other hand, unlike other disciplines, legal theory does not create all of the concepts that it uses, but extrapolates them from its object, i.e. from the law itself. This is the case e.g. for "constitution", "contract", "interpretation" etc..... since they are rooted in particular historical circumstances, they are often ill suited for a general analysis or for the analysis of systems that are different, so that historians, even legal historians, (or anthropologists) can make little use of them.

Thirdly, a large and important part of legal theory is kept pure from the social sciences, including history, for several reasons, but in particular on the assumption that the law is not a system of facts and thus cannot be analyzed through the principle of causality.

This essay is an attempt to bridge the disciplines, not by adopting a multidisciplinary approach, but by using some of the concepts of legal theory to examine one historical puzzle which for the purposes of this paper is mainly two-fold: the emergence of the State and the exploration of explanatory observations.

My point of departure is Kelsen's well known and much criticized theory of the identity of Law and State. Kelsen's thesis is directed against the traditional dualist theory that holds that they are different entities, and either views the State as an objective and independent being that produces law or alternatively considers that it is the law that constitutes the State by empowering its authorities to act and produce law.

He blames the dualist theory for resting on two assumptions both wrong : that the law that empowers the State is some form of natural law or that the State can be 
defined in any other way than as a legal order'.

He objects that natural law does not exist and on the other hand that it is impossible to give an independent definition of the State. First it is impossible to give a sociological definition of the State, because, any attempt at such a definition will inevitably rely on legal elements. For example, Max Weber defines the State « as an entity which successfully claims a monopoly on the legitimate use of violence », but this monopoly is obviously not a de facto monopoly, because there are many acts of violence that are not committed by the State; it is a monopoly of the legitimate use of violence. The word "legitimate" does not imply that the use of violence by the State is just or in accordance with certain fundamental values. It means that acts of violence are performed according to legal rules. On the other hand, the State is an abstraction and thus incapable of exercising violence. Only human beings can exercise violence, but the acts accomplished by some individuals are imputed to the State and this is only made possible by way of legal rules that prescribes which acts by which individuals will be imputed to the State 2 .

Secondly, it is impossible - according to Kelsen - to give a purely legal definition of the State. If we look at the traditional definition by elements (a people, a territory, a public government) we can see that it is impossible to define these elements taken one by one without a tautology: a people is not an objective entity that could be defined independently of the State; the people of France do not possess any common psychological, religious or ethnic characteristic. They can only be defined as the class of human beings who are subject to the French State or, in other words to the same legal order; similarly, the territory of the State can only be defined as that portion of space that is subject to a particular State or, in other words, to the legal order of that State; moreover, it is the State that decides on the content of the class of subjects that constitute the people or on the limits of the portion of space that constitutes its territory; finally, the public government is the government of the State or the highest power in the

\footnotetext{
${ }^{1}$ KELSEN (Hans) (1928), Der soziologische und der juristische Staatsbegriff; Kritische Untersuchungen des Verhältnisses von Staat und Recht, 2nd edit., Tübingen,

2 ibid.
} 
legal order and what constitutes the government of a State is also decided by the State. Thus, these three elements cannot define the State because they are themselves defined by the State and since we can in each case substitute in the definition the words "legal order" or "Law" for "the State", they are just two names for one and the same reality.

To say that the State is just another word for the law is not denying the hard reality that it uses force, that there are bureaucrats, police and prisons. It only means that such institutions are empowered by legal norms, act by means of legal norms, and that all those norms can only be identified because they are elements of a legal system. For Kelsen, the monist theory has an enormous advantage, that of dissolving the problem of the relation between the Law and the State, i.e. the question whether the State can be subject to Law.

We are left however with another problem : we can certainly replace the words "the French State" with "the French legal order", but we cannot replace "the international legal order" by the "international State", or "the medieval legal order" by "the medieval State" because there is no such thing as an international State and the feudal system of the Middle Ages was different from the government that we call a State. Kelsen is thus constrained to introduce in his definition a new element : centralization. Some legal orders are centralized, i.e. specialized organs, such as a parliament, an executive, a system of courts, have a monopoly of the production of the most general norms, that are valid for the entire population, on the entire territory, and whose addressees are the subjects, whereas others, like the international legal order, are decentralized because the norms are produced, interpreted and applied by the addressees themselves. Thus, the French or the German legal order are states, but the international legal order is not.

Unfortunately, this distinction does not really help because, taken together, the central organs of the legal orders constitute precisely what the classic dualist theory called a "State". Kelsen is forced to admit that there are two different concepts of the State : the State lato sensu, which is identical with the legal order, and the State stricto sensu, which is the system of organs that have the power to produce norms. But then we are left with the same puzzles. If Law and State are one and the same thing, then the question of their mutual relation is obviously nonsensical, but the State stricto sensu is not the same thing as the Law and we are thus confronted with the same initial 
questions: is this State the source of law or is the law the basis of the State ? can the State be limited by the law that it has created?

Thus, Kelsen seems to have failed. However this failure is a felix culpa. It provides what seems to be a fruitful opportunity to analyze the relation between the State lato sensu and the State stricto sensu. In a brief introduction to the second edition of his "Der soziologische und der juristische Staatsbegriff", Kelsen remarks that the former concept is presupposed by the latter ${ }^{3}$.

He probably understood this as a purely logical or conceptual connection because one cannot think of the State stricto sensu without conceiving it as the set of those organs that produce the norms that are at the top of the entire legal order, i.e. at the top of the State lato sensu.

Nevertheless, we can also view it as a real historical and possibly also causal connection. Such a connection however is only possible if both are historical phenomena. According to a common view, this is true for the State stricto sensu, the modern State, which has emerged some time at the end of the $16^{\text {th }}$ or in the $17^{\text {th }}$ century, but not for the Law, which is usually supposed to have existed in every human society. This view is not only that of natural law, but of positivists also. For example, Kelsen defines Law simply as an immanent order of constraint, a definition that works equally well for national legal systems, international law, feudal law or the law of primitive societies. However, when we consider not the general definition but the main characteristic of the legal system, as we know it, namely its hierarchical structure, described in Kelsenian terms as a hierarchy that is both static and dynamic, the general and universal definition loses its validity : all legal systems are not structured in this manner. It is only towards the end of the $16^{\text {th }}$ or in the $17^{\text {th }}$ century that we find a hierarchy resembling that model.

Naturally, this is not enough to allow us to speak of a causal connection, but I want to test the hypothesis that it is the emergence of the legal system that led to the emergence of the State, so that it is not the State that creates the law but the law that creates the State.

3 ibid. 
The State is not understood here merely as a complex of organs but as a type of justificatory discourse held by agents in a specific political system. As was the case with Kelsen's definition of the State as the legal system, defining it as a discourse does not mean a denial of its political and material reality. It allows to distinguish it from other forms of political systems. In every political system power is exercised by force, but in the State the use of force is regulated by law and justified by specific principles, different from those invoked in other systems. The State is thus a system of constitutive principles, in the sense that we recognize a State when agents play the game of State, i.e. justify their decisions by invoking such principles as sovereignty, representation, distinction between the office and the office holder, distinction between public and private law, between State and civil society, personality or continuity of the State, etc. In this essay, however, I focus mainly on "sovereignty".

The hypothesis has two branches. Firstly, the law, understood as a hierarchy of norms, has emerged as the result of an autonomous and spontaneous process that had started in the late Middle Ages and was almost accomplished at least as an instrument of legal argumentation by the end of the $16^{\text {th }}$ century. Secondly, the emergence of the hierarchy of norms has given rise to the emergence of the constitutive principles of the State.

One last remark : I will not consider the emergence of these principles from the point of view of a history of political thought, studying Bodin, Hobbes, etc.. in order to construct a genealogy of concepts. Great thinkers have played a decisive role in the development of the theories of the State, and an analysis of their works is indispensable, but it has already been done by the most excellent scholars. Moreover, we still need to explain why these ideas have been discovered at this particular moment. It is not sufficient to look at political thought as an autonomous sphere where ideas are transmitted from one author to the other or appear as replies to others as well as responses to political problems of their time. There is also a need to understand why they were so quickly received and put to use by political and legal agents.

Nor will I consider them from the point of view of a history of institutions - this also has already been done - but from that of legal argumentation on the assumption that the hierarchy of norms is a specific style of legal argumentation.

I will proceed in four steps; first, I will examine the methodological difficulties 
that historians face when they examine the date for the emergence of the State, in particular the difficulty in finding a definition and I will propose a definition based on the hierarchy of norms. Secondly, I will then look for a hierarchy of norms in the Middle Ages and in the modern period, then for the emergence of sovereignty and finally attempt to relate the two elements.

\section{A. The problem of the origin of the State in the Middle Ages}

Any theory on the origin of the State must rely on a definition. Reflecting on the trends of French historical research on the State, the legal historian Albert Rigaudière remarks that during the major part of the $20^{\text {th }}$ century, "legal historians have limited themselves to a history of institutions, mostly without any deep analysis on the concept of State...they have describe the nuts, bolts and wheels rather than the global mechanism and the entity that this mechanism constitutes"4. Only after 1980, have they started to analyze the medieval conception of the State.

This distinction between institutional and conceptual analysis is not as clear as one might wish. When traditional historians describe institutions of the late middle ages such as the King, the courts or the curia regis, they cannot avoid relying on political ideas and using expressions drawn from the language of the time. It would indeed be impossible for instance to relate the dispute between the French King Philippe le Bel and Pope Boniface VIII in 1296 without referring to arguments used by both parties, i.e. to their respective doctrines 5 . On the other hand, those authors who, like Rigaudière, profess to analyze the medieval conception of the State use not only medieval terms derived from Roman law like imperium, majestas, jurisdictio, regimen.... but inevitably they too must rely on modern ones. Rigaudière himself uses terms such as "State", "sovereign' or 'legislative power", which, needless to say, appeared much later.

Historians are thus confronted with a dilemma: either they use ancient concepts

4 RIGAUDIĖRE A., 2003, Penser et construire l'État dans la France du Moyen Age. XIIIe-XVe siècle, Comité pour l'Histoire économique et financière de la France, Paris.

${ }^{5}$ CHÉNON Emile (Contributeur: Olivier-Martin, François), 1926-1929, Histoire générale du droit français public et privé des origines à 1815. Tome 1, Période gallo-romaine - Période franque - Période féodale et coutumière, Paris, Sirey, p. 933ff. Chénon and Olivier-Martin are precisely the target of Rigaudière's critique. 
and they have no way of knowing whether these concepts are related or not to a construction that we may rightly call a State or they can try to use later concepts and find that they correspond neither to the language nor to the reality of the Middle Ages.

The only way out of the dilemma is to devise a metaconcept that would allegedly be timeless and call "State" any political form that roughly fits the definition and deny that qualifications to those that don't. But, as historians are well aware, the choice of a definition predetermines the answer to the question of the emergence of the State ${ }^{6}$. If the definition is too broad almost every political entity with a territory is a State, except primitive societies. In that case, "the origins of the state lie in the transition from the nomadic subsistence of hunter gatherers to more agrarian societies, characterized by organized agriculture"7. Naturally, most historians will seek to narrow the definition as have all those quoted above, and find characteristics not of the State but of the "modern" State.

Unfortunately, the same difficulty arises with the definition of the modern State. Even for the modern State, as we know it in the 21st century, there is no generally accepted definition. True, we can easily find a criterion such as recognition in international law; however, a criterion of this nature would not be helpful to identify a State prior to the emergence of international law. Notwithstanding, a criterion is not a definition.

Historians who have studied the Middle Ages generally rely on simplified versions of the most frequent definitions of the modern State. Thus, J ean-Philippe Genet defines the modern State "as a State, whose material base rests on a public taxation system, which is accepted by political society (with a territorial dimension superior to the city) and whose subjects are all concerned" ${ }^{\prime}$. Similarly, John A. Hall derives his definition from Max Weber ${ }^{9}$. Accordingly, a State has four elements: a

${ }^{6}$ RIGAUDIÈRE, op. cit. p. 181.

7 HAY C., LISTER M., MARSH D. (ed.), 2006, The State. Theories and Issues, New York, Palgrave MacMillan,

8 GENET J ean-Philippe, La genèse de l'État moderne, in Actes de la recherche en sciences sociales. Vol. 118, juin 1997, pp. 3-18.

9 HALL J ohn A. (ed.), 1994, The State. Critical Concepts, London and New York, Routledge 3 vol., , p.. 331. ff. 
system of differentiated institutions, centralization, a circumscribed territory, and a monopoly of the production of law by an authority, with a monopoly of physical violence. Clive Holmes mentions a few elements: monopoly of violence, a centralized courts system, professional lawyers...10.

Others will recognize the emergence of the State when they see "sovereignty" or the signs of sovereignty, such as a legislative power (Rigaudière), or the fact that power cannot be appropriated and is depersonalized.

Some of these definitions may lead to strange results. Take for instance Genet. He mentions as a key element a public system of taxation, accepted by political society. However, how do we define "acceptance"? Is it the simple fact that there is no effective resistance against taxation and that taxes are actually being collected? But in that case whenever there is an effective tax system, there is acceptance and we must call "State" the Assyrian or the Aztec empires. Or does it mean, as Genet himself asserts, representative government or at least some form of dialogue with civil society and in that case the absolutist State ceases to be a State?11

In any case, the defining terms must always be defined, and the intermediate definitions also predetermine the answer to the question of the origins. For example, if one considers that the State emerges with the enactment of general rules, one may find a State in Western Europe as early as the $12^{\text {th }}$ century ${ }^{12}$. If, on the other hand, one sees the essence of the State in a centralized bureaucracy, then we will have to wait until the $16^{\text {th }}$ century.

Centralization itself is not a very clear concept. As Bernard Guenée rightly warns us, a distinction should be drawn between personal centralization (the king gets hold of new fiefs), institutional (creation of judicial, financial or representative bodies with jurisdiction over the entire territory) or geographical (existence of a capital city). Again,

\footnotetext{
10 HOLMES Clive, Les instruments juridiques du pouvoir et l'Etat dans l'Angleterre du début de l'époque moderne, in PADOA-SCHIOPPA, A. (ed.), 2000, J ustice et législation,Traduit de l’anglais par Marie-Anne de Kisch, Texte français établi par Albert Rigaudière, Paris, PUF, p. 315 ff.

${ }^{11}$ Genet writes that "À tout prendre, l'État de Louis XIV est à bien des égards moins moderne que celui de Charles V » p. 5.

12 GIORDANENGO Gérard, 1989, Le pouvoir législatif du roi de France (XIeXIIIe siècles) : travaux récents et hypothèses de recherche. — Bibliothèque de l'École des Chartes, t. 147, , p. 283-310.
} 
depending on the definition of centralization, we will find different dates for the emergence of the State ${ }^{13}$.

In the same way, we may use sovereignty as a criterion of the State, but there are many different ways to establish that the State is sovereign. We may for instance assume that the State is sovereign when we discover the presence of the words "sovereign" and "sovereignty" in the writings of a certain period. However many questions remain: what if these words appear at different moments and in different contexts, as it is indeed the case? What kind of writings are we looking at? Those of the great thinkers, but how do we know whether when they say that the State is sovereign they describe the actual State of their time, seek to magnify the power of the King, recommend the creation of a strong authoritarian State or provide arguments for some current legal dispute? In the former case, they may give a true or a false description, in the latter, they may have an influence or not. Moreover, the word may have different meanings for different authors of the same period. Many historians claim that the word "sovereignty" has been coined by Bodin in the $16^{\text {th }}$ century, but others that "sovereign" is much older and can be found in Beaumanoir in the $13^{\text {th }}$ century; yet, the presence of the word proves nothing if these authors don't refer to the same reality or the same concept ${ }^{14}$.

Alternatively, historians who wish to maintain that the State was already sovereign in the Middle Ages, may argue that, even if the words were different, the reality or the concepts were the same ${ }^{15}$. For example, they can say that "auctoritas" or "potestas" or "imperium" or "majestas" either were parts of a more general concept of sovereignty, for which there was no word or that they had the same functions as sovereignty.

13 GUENÉE Bernard. Espace et État dans la France du bas Moyen Âge, in Annales. Économies, Sociétés, Civilisations. 23e année, N. 4, 1968. pp. 744-758.

${ }^{14}$ COURTINE J-F., L'héritage scolastique dans la problématique théologico-politique de l'âge classique, in ROBINET André, 1985, L'Etat baroque : regards sur la pensée politique de la France du premier XVIIe siècle, Paris, p. $91 \mathrm{ff}$.

15 Thus Marcel DAVID writes 'la chose peut exister avant qu'ait été forgé le terme même dont nous nous servons présentement" (La souveraineté du peuple, Paris, PUF, 1996, p.18). The same view had been held by other historians, notably by WILKS M.J , 1963, The problem of Sovereignty in the Later Middle Ages, Cambridge, University Press. For a contrary opinion, see e.g. QUARITSCH (H.), 1986, Souveränität: Entstehung und Entwickung des Begriffs in Frankreich und Deutschland von 13J h. bis 1806, Duncker \& Humblot, esp. p. 34 : Uber die Unmögligkeit 'mitttelaterlicher' Souveränität". 
Thus, most of these definitions have been chosen with the purpose of proving some thesis: either that the State was created in the Middle Ages (some even give a precise date) or that it has emerged later, in the $16^{\text {th }}$ century. Historians generally like to show that an institution is more ancient than one might think. Recently, in France, after the power of the Constitutional council had been expanded, historians, who had previously argued in the past that judicial review of the constitutionality of statutes was absolutely contrary to a French tradition of the supremacy of statutory law, now argue on the contrary, that in the $18^{\text {th }}$ century already the "Parlements" already practiced judicial review ${ }^{16}$.

But historians or political theorists may have other powerful ideological interests at stake. Depending on whether they favor an authoritarian or a moderate State, the role of legislation or that of the judiciary, they will try to show that the State has been created by statutory law or by courts or by centralization or by wars, that the "true" characteristic of the State is that it is absolute or alternatively that it is subject to higher law, that it is related to Christianity or to secularism, that it is a force that requires external countervailing mechanisms such as courts or alternatively that courts are part of the State and thus constitute internal checks.

It is naturally impossible to falsify part - or all - of these definitions, unless we believe that there is an essence of the State. They are not descriptions of an objective reality but stipulations. It does not follow that they should be dismissed altogether. Stipulations are not susceptible of being true or false, but they can be evaluated for their capacity to help in the discussion of some specific problem.

Naturally the stipulated definition should not predetermine the outcome and we must be aware of committing the Gorenflot fallacy: In his novel, la Dame de Montsoreau, Alexandre Dumas portrays a monk, brother Gorenflot, who, being very hungry on a Friday during Lent, and wishing to eat a capon without sinning, finds a

16 SAINT BONNET F., Un droit constitutionnel avant le droit constitutionnel, dans Droits, PUF, 2000, $\mathrm{n}^{\circ}$ 32, p. 7-20; Le Parlement, juge constitutionnel (XVI-XVIIIème siècle, in Droits 34, 2001, pp. 177-197s.; RENOUX-ZAGAMÉ M.-F., Juger la loi au nom du droit naturel : fondements et portée du contrôle des Parlements de la monarchie, in Cahiers du Conseil Constitutionnel, 2010; DI DONATO F., La costituzione fuori del suo tempo. Dottrine, testi e pratiche costituzionali nella Lunga durata, in Quaderni constituzionale (forthcoming). 
wonderful solution in baptizing the capon "carp"17.

In order to avoid the Gorenflot fallacy and test the hypothesis that the State is a form of political power exercised through law and that it emerges as a consequence of the structuration of a legal system, we must define it by some other criterion than the structure of the law itself.

Sovereignty is an interesting candidate. It has often been mentioned as a constitutive element of the State. "Constitutive" generally means "essential" and most lawyers would agree that all states are sovereign and no entity that is not a State is fully sovereign. However, the term can also be understood in Searle's sense of a constitutive rule, one that defines the game that is being played ${ }^{18}$. In the present case, we can see that in the modern State authorities use arguments resting on the theory of sovereignty in order to justify their decisions. This is one of the principles that define the game of the State. Other constitutive principles include personality of the State, the distinction between the State and the authorities that exercise its sovereignty, the distinction between public and private law and a reference to the rule of law. In the present paper, I must limit the analysis to sovereignty in order to ascertain the extent to which sovereignty as a constitutive principle emerges as a result of the hierarchical structuration of the law.

\section{The emergence of a hierarchy of norms}

\section{A. What is a hierarchy of norms ?}

As we have seen, the State can be characterized as a type of political system where power is exercised through or by means of the law. This is the reason why Kelsen could rightly say that "J eder Staat ist ein Rechtsstaat" (every State is a State of law). Law is a means of political power because of its specific structure, the hierarchy of norms.

The term "hierarchy of norms" is obviously a metaphor that is commonly used to describe a great variety of relations between norms that are not of equal value.

\footnotetext{
${ }_{17}$ In English "Chicot the jester (la dame de Monsoreau) 1956, London, Collins,, chap. 8 : "In the name of Bacchus, Momus, and Comus, trinity of the great saint Pantagruel, I baptize thee, carp," said Gorenflot. 18 SEARLE, J.R. (1969) Speech Acts: An Essay in the Philosophy of Language, Cambridge University Press, Cambridge, $\mathrm{p} 33$.
} 
Sometimes, we speak very loosely of a hierarchy between two norms merely when, in case of a conflict, one is made to prevail over the other, whatever the basis for that prevalence. For example, the hierarchy of norms is even sometimes confused with a situation where there is a conflict between two norms and one is not the basis for the validity of the other, and where the conflict is resolved not by declaring one of the rules invalid but simply by using some general principle like "lex posterior" or "lex specialis". In some cases, one may also speak of a hierarchy of norms lato sensu when we assume that one norm prevails or ought to prevail over the other even if the latter cannot be voided in case of conflict. In that sense, we find such a hierarchy in every political system. It is not even necessary that the two norms belong to the same normative system. Indeed, some view the relation between moral and legal norms as hierarchical. More narrowly, we also speak of a hierarchy between two norms whenever one of them is only valid when it is based on the other and in case of a conflict the prevalence of one norm over the other depends not on their respective content but solely on the fact that it has been produced by a higher authority or in a higher form. For example, in French law there is a hierarchy between the constitution and statutes because the constituent power is a higher authority that has empowered Parliament to enact statutes and because statutes must conform to the constitution. There is also a hierarchy between organic laws and statutes, although they are being both enacted by the same Parliament, because they are produced by means of two different procedures and statutes must conform to organic laws

However, in order to understand the way in which political power operates by means of the law, we need to consider not two single norms but the more complex structure of the whole system. Kelsen has described this structure as a hierarchy that is at the same time static and dynamic.

A static hierarchy is one in which a lower norm is valid if and only if its content conforms to the content of a higher and more general norm. There are several possible conceptions of conformity, but it is usually thought that it need not be a logical relation, such that the content of the lower norm is deduced from the content of the higher norm and that it suffices that the content of the lower norm can be subsumed under the higher norm or simply that it does not contradict it. 
A dynamic hierarchy is one in which the lower norm is valid if and only if it has been produced according to the procedure laid out and by the authority empowered by a higher norm.

There are also various conceptions of "validity". For some legal theorists it is synonymous with "bindingness", and in that case "bindingness" sometimes refers to a moral obligation to obey the norm, sometimes to a pure legal obligation, while it can also be used to refer to the character of a norm that belongs to the system and is then synonymous with "membership"19. Norberto Bobbio has thus convincingly argued that Kelsen's theory of the hierarchy of norms has brought an entirely new perspective: instead of defining the law as a collection of legal norms - which requires an impossible definition of the single legal norm as a command backed by threat or as a hypothetical judgment - the legal norm is defined or identified by the system of which it is an element ${ }^{20}$. A norm is a legal norm when it belongs to a legal system, and it belongs to a legal system when it is an element of static and a dynamic hierarchy. This is the reason why there can be no such thing as an invalid legal norm and why validity is not a matter of degrees: something is either a valid legal norm or no norm at all. But, the question of validity must be clearly distinguished from that of applicability: the fact that a given concrete situation ought to be regulated by one norm rather by another does not mean that the former is valid and not the latter.

It follows that a given act, whether a court decision, a command by an officer, a contract, a marriage, is valid when it has been accomplished by someone who has been granted by a higher norm the power or the right to produce it and when it is not contrary to the same or another higher (substantive) norm. How do we know that this is the case? When the authority that accomplishes the act claims that it is valid and another authority does not successfully challenge that claim. If it is challenged, then it is on the basis that the former authority has not been empowered to produce the act or that it has exceeded its powers or that the act is contrary to some higher substantive norm.

\footnotetext{
19 ROSS A., Validity and the Conflict between Legal Positivism and Natural Law, in Revista J uridica de Buenos-Aires, IV, 1961. Also in M. J ORI (ed.), 1992, Legal Positivism, Dartmouth, Aldershot , p 149-166. 20 BOBBIO N., 1960, Teoria dell'ordinamento giuridico, Torino, G. Giappichelli, .
} 


\section{B. The absence of a hierarchy of norms in the Middle Ages}

In the Middle Ages, there is no hierarchy of norms in the sense described above, although it began to take shape at the end of the period.

During the first centuries, there is a hierarchy but it is a hierarchy of persons and bodies, not of norms. The king is only a superior lord, a suzerain. He must respect the freedom of his vassals and has no power over his vassal's vassals. His rare laws require the advice and consent of the barons ${ }^{21}$.

Even later and until the $15^{\text {th }}$ century, there is no legal system to speak of. Naturally there are norms, the king does enact some laws and historians speak of a "renaissance" of the legislative power in the 12th century. However, the term law is not fully adequate : a law is a general rule and the king does not have a monopoly on the production of laws; other authorities, the barons, the courts or some cities can also enact general rules and there is no specific jurisdiction for each of these authorities, so that several can issue rules on the same subject. Indeed in medieval theory adjudicating means not only trying cases, but also making general rules outside of litigation ${ }^{22}$. Moreover the king's laws are not necessarily general and the same forms and procedures may be used to make particular decisions, like appointments or gifts ${ }^{23}$. A further characteristic of modern legislation is missing: it can have any possible substantive content. However, in the Middle Ages not only are the king's laws rare, they also do not interfere with what we would call today "private law", which is left entirely to custom ${ }^{24}$.

The main characteristic of laws in the modern sense is absent: today, we see them as an expression of the will, not of reason. True, The king's "legislative power" is justified by maxims of Roman law that seem to presuppose unilateral power, "princeps legibus solutus est..." and « quod principi placuit legis habet vigorem". However, at that

21 The word "beneplacitum" is mentioned explicitly in an ordinance of 1155, cf. SAINT-BONNET F., SASSIER Y., 2011, Histoire des institutions avant 1789, Paris, Montchrestien, 4è édit., p. 170.

22 RIGAUDIĖRE A., GOURONA., 1988, Renaissance du pouvoir législatif et genèse de l'Etat, Montpellier : Socapress ; preface by Albert Rigaudière, esp. p. 9.

23 KRYNEN, De nostre certaine science...". Remarques sur l'absolutisme législatif de la monarchie médiévale française, in RIGAUDIĖRE A., GOURON, pp. 131s.

${ }^{24} \mathrm{cf}$. GIORDANENGO, fn 12. 
time, these formulas are not symbols of absolutism. The king is not solutus from religious and moral rules, which are anyway difficult to distinguish from legal ones, and he must act according to reason. The maxims are thus never interpreted as conferring him the power to act on his own free will ${ }^{25}$. Until the late $13^{\text {th }}$ century, the binding character of the "law" does not result from the unilateral character of the king's decision, but resembles a contractual relationship - the barons still swear an oath to the king ${ }^{26}$. This is reflected in practices and procedures. The king's own language does not imply that he intends to impose his own will ${ }^{27}$. In fact, even in Roman Law these maxims were not a mandate for the absolute authority of the prince ${ }^{28}$.

True, the view that the roman maxims do not give the king an absolute power is not accepted by all historians. Thus Krynen writes that "total submission to divine law and natural law in no way limits the king's total discretion in producing positive law". The king enacts law ex certa scientia, meaning that he is fully conscious that he is acting against established law ${ }^{29}$.For Krynen, this means that the king's decision to make a new law is justified not by its conformity to reason but on his free will. However, the argument is not convincing: one should not assume that reason is only knowledge of existing law or custom. It is also knowledge about the adequacy or inadequacy of the customary rule to a certain state of affairs. If the king legislates contra jus, this is only because he knows ex certa scientia that the existing custom is contrary to reason ${ }^{30}$. $\mathrm{He}$ justifies his decision by claiming not that he exercises his will but that the substance of the decision is rational. In fact, the king very rarely uses the argument that his will is what makes the law and the phrase "car tel est notre plaisir" will only be used at the end of the $15^{\text {th }}$ century ${ }^{31}$.

25 RIGAUDIÈRE A., Penser et construire l'État dans la France du Moyen Age. XIIIe-XVe siècle, Comité pour l'Histoire économique et financière de la France, Paris 2003, p. 50.

${ }^{26}$ RIGAUDIÈRE A., Ibid. p. 229s.

27 RIGAUDIERE, A., Législation royale et construction de l'Etat dans la France du XIIIè siècle, in. RIGAUDIËE A., GOURON A..p. 214.

${ }^{28}$ Brian Tierney, quoted by Ken PENNINGTON, 1993, Laurentius Hispanus and Pro ratione voluntas, in Popes, Canonists, and Texts 1150-1550 (Collected Studies Series 412; Aldershot: Variorum.

29 KRYNEN, De nostre certaine science...".p. 132.

30 SAINT-BONNET F., SASSIER Y.,, p. 212.

31 DUCCINI Hélène \& HERMANN Christian 2000, Textes et documents: les monarchies française et espagnole du milieu du XVIe siècle à 1714, Paris, Editions du Temps, ; DE MAS-LATRIE Louis. 1881, De 
The phrase "hierarchy of norms" sometimes used by historians in this context is misleading. It refers to the fact that in case of a conflict, some norms are made to prevail over others because of their subject matter or because of differences in the procedure to lay them down. But this relation is of the type described above as a horizontal order of preferences.

Most important, legislation is not a normal form of governance. Laws are rare and kings often prefer to act by other means that the enactment of general and permanent rules and even when they do legislate, the laws are not at the top of a hierarchy and they do not constitute the basis for the validity or the binding character of all other norms ${ }^{32}$.

It is true that historians sometimes speak of a hierarchy of norms in the $14^{\mathrm{TH}}$ century when they describe the fundamental laws of the realm, like the salic law, which they equate with constitutional rule 33 . In support of this idea, they refer to expressions used by contemporaries, such as "constitution" or "the first law of the French", as revealing a will to place this rule at the highest level. However, such "rules" are very different from a constitution in a modern State: they have been established by a long practice and cannot be altered at will; they do regulate the mode of accession to the throne - in this sense they are constitutive - but they do not define the powers of the various authorities, not even the king's and in the Middle Ages they cannot be used as arguments to evaluate other norms.

Finally, all the norms are not part of one single legal system. In the Middle Ages several legal systems coexist. Even if the royal order had some sort of hierarchical structure and resembled a modern legal order, we would still find beside it canon law,

la formule « Car tel est notre plaisir » dans la chancellerie française in: Bibliothèque de l'école des chartes. , tome 42. p. 560-564,

32 "Dans la politique édictale de Louis XI, les interventions qui ressortissent indéniablement à la législation côtoient ainsi des formes différentes de normativité. La généralité et la permanence qui caractérisent la loi moderne n'apparaissent pas comme les critéres les plus adéquats pour analyser la pratique normative" (MARTIN Frederic F., 2009, Justice et législation sous le Règne de Louis XI. La norme juridique royaleà la veille des Temps modernes, LGDJ , Paris , p. 206.

33 RIGAUDIERE, A., Pratique politique et droit public dans la France des XIVème et XVème siècles, in Archives de Philosophie du dr, 1997, t 41 Le privé et le public, p. 83 ff. 
customary law and law arising from judicial interpretations ${ }^{34}$. Only later on will these various systems be integrated into one, when canon law or customary law will be applicable on the basis of an explicit or implicit authorization by the king ${ }^{35}$.

\section{The emergence of a hierarchy of norms in the $16^{\text {th }}$ century}

By contrast, we witness the structuration of a hierarchy, at the beginning of the $15^{\text {th }}$ and $16^{\text {th }}$ century. The hierarchy is constructed both from the top and from below.

From the top, it is obviously legislation that plays a major part. Other factors of the construction of the State, like administrative centralization, a court system, taxes, armies, are themselves products of legislation.

From below, because those who produce local or particular rules justify them by invoking not only morals, religion, or tradition, but also a superior legal norm that can ultimately be traced to the king. This is the case with administrators, courts and local authorities.

\section{The creation of a hierarchy of norms from the top}

Legislation does not produce a hierarchical legal system merely because it consists in general rules, but only because these rules authorize directly or indirectly the production of all other rules, regulate their content and constitute the sole basis for their validity. This happens when by legislation other sources are integrated into one legal system. Naturally, what we will be describing here is not an empirical reality. The hierarchy of norms is not an empirical phenomenon. When we say that norms are objectively valid because they ultimately have their basis in a law, we only refer to an argument that they are valid in that sense. Indeed, this is precisely the claim made by the king. The argument may or may not succeed rapidly and success obviously results not only and even not primarily from the quality of the argument but from relations of

\footnotetext{
34 KRYNEN Jacques, 1993, L'empire du roi; idées et croyances politiques en France XIIIè-XVè siècle, Paris, Gallimard, , WEIDENFELD Katia, 2001, Les origines médiévales du contentieux administratif, XIV-XVè siècles, Paris, De Boccard, ; RIGAUDIERE A. Penser et construire l'Etat au Moyen-Age...p. 20s.; BEAUD Olivier, 1994, La puissance de l'Etat, Paris, PUF, .

35 MARTIN Frederic, op. cit. p. 313.
} 
power, but it is sufficient to recognize that it is in the king's best interest to use it and sometimes in best interest of other actors to accept it.

The most important source to be integrated is custom. At the end of the hundred years war, in 1453, Charles VII enacts the ordinance of Montil-les-Tours, to mandate that all customs of the kingdom be written down. This is not a mere encouragement to make customary rules more available, nor is it - contrary to what some historians of the last century have mistakenly argued - an acknowledgment by the king of existing local rules and a renunciation to exercise his own legislative power ${ }^{36}$. On the contrary, this move means that from now on customs will be binding not because they are ancient but because the king has ordered that they be applied. The ordinance explicitly forbids "all attorneys of the kingdom to invoke or propose other customs than those which will have been written and granted"37.

The official justification is the need to limit uncertainty in adjudication and lengthy judicial proceedings, but the truth is the conscious will to make the king's laws the only real source of law. The writing is evidence for the existence and the substance of a custom, but also it will give the authority of the law to customs. Domat's will stress in the $17^{\text {th }}$ century that "in a State that is subject to a sovereign, customs are only established and settled by his authority" 38. From now on, at least in principle, there is no longer a distinct and autonomous order of customary law, but customary law is a subsystem of the unified legal order. Thus, in case of a conflict between a statute (a law emanating from the king) and a custom, the former prevails. Here is one example: customary law allowed husband and wife to bequeath their possessions to each other; on the other hand, there was a royal ordinance of 1560, prohibiting widows to give or bequeath to their second husbands - the purpose of the law was to protect the children

36 This view has been criticized by Jacques KRYNEN, « Entre science juridique et dirigisme: le glas médiéval de la coutume», Cahiers de recherches médiévales 2000 [On line], 7|: http://crm.revues.org/892. See also GRINBERG Martine. La rédaction des coutumes et les droits seigneuriaux : nommer, classer, exclure. In: Annales. Histoire, Sciences Sociales. 52e année, N. 5, 1997. p. 1017-1038.

37 cited in SEVE R. , Le discours juridique dans la première moitié du XVIIème siècle, in ROBINET, André, 1985, L'Etat baroque : regards sur la pensée politique de la France du premier XVIIe siècle, Paris, p. $121 \mathrm{ff}$, esp. p. 126. The full text is to be found in Isambert, T. ix, p. 252-3.

${ }^{38}$ Quoted by KRYNEN 2000. 
born from the first marriage -; The Paris court decided to apply the ordinance and not the customary rule. A contemporary commentator explained that an ordinance is a general law of France from which customs cannot derogate and that no Frenchman can be excused for failing to know it 39 .

It is true that the ordinance of Montil-les-Tours was not immediately effective but it was soon followed by others. Particularly striking is Charles VIII's ordinance of 1499, which rules that in the process of writing down customs, they should be interpreted and, if need be, reformed. This process will actually take place during the $16^{\text {th }}$ century and will be carried on until the Revolution.

What is remarkable is that, with the integration of customary law and ecclesiastic law in one legal system, the whole domain of private law is indirectly under statutory law. The integration of private law is thus an important element in the construction of the hierarchy of norms from a double point of view. First, if private law is regulated directly by a royal law, there is a hierarchy between that law and norms created by individuals, like contracts or testaments, but the hierarchy of norms also exists when private law is regulated by custom, because in that case it is regulated indirectly by the legislation, since custom is only valid on the basis of a king's law. Thus, the only difference between a court decision that applies an ordinance and another that applies a customary law, is that we have one more level in the hierarchy of norms, between that of legislation and that of courts. This difference is indeed minimal and we see legislation that mandates at the same time to apply ordinances and custom.

In kelsenian terms, we now tend to have a hierarchy with three levels: statutory law, custom, courts decisions. The hierarchy is both dynamic and static. It is dynamic because the higher level, the ordinance or statute has prescribed the writing and the reformation of customs. What counts as custom is what has been written down according to the king's ordinances. It is static because the custom will be binding only if its content does not conflict with the content of an ordinance - indeed some ordinances

39 « L'ordonnance est une loi générale de la France à laquelle les coutumes ne peuvent déroger et nul des français ne peut excuser de l'ignorer» CHARONDAS LE CARON, jurisconsulte parisien,. 1596Responses du droict François, confirmées par arrests des cours souveraines de France et rapportées aux loix Romaines, ... - Lyon : , p. 207. 
have abolished customs considered to be unreasonable - and because the content of court decisions must derive from customary rules.

Alternatively, the lowest level is that of norms made by private individuals on the basis of either statutes, like testaments or contracts, or customary law, when there are no statutes. Custom may still be a source of law, but the king's laws are the source of custom.

The second source to be integrated by legislation is judge made law. The king gradually develops a system of royal courts that gradually acquires a quasi monopoly of adjudication. Thus, in 1539, by the Ordinance of Villers-Cotterêts, Francis I limits the jurisdiction of ecclesiastic courts over lay persons exclusively to matters pertaining to spiritual matters such as sacraments. In the same ordinance, he offers feudal lords to buy their power to render justice ${ }^{40}$. When they keep it is argued that it is only by delegation from the king and when he delegated that power to the local lords, that was not to exercise that right in full sovereignty but only in the name of the lord sovereign"41.

In 1566, the ordinance of Moulins strictly limits the jurisdiction of city courts to matters of police. The royal ordinances that set up civil and criminal procedure make clear that the power of the courts derives from the king. Civil and criminal courts also are considered as delegates of the king. Even when judges own their offices (because they have bought or inherited them) and when they hold them in perpetuity, they are still delegates, because the rule of perpetuity has been established by the king and it is the king who mandates the application of ordinances and customs ${ }^{42}$.

The king's exercises his control over the courts' decision by several means. One is that he can always evoke a case pending before a court and decide it in his council. The other is the procedure of cassation, which to this day is an essential characteristic of the French legal system. Cassation is different from an appeal. It is not a dispute between the same parties than in the lower courts but between the decision of a lower court and

${ }^{40}$ LEBIGRE Arlette , La justice du Roi. La vie judiciaire dans l'ancienne France, Paris, Editions Complexe, 1988, p. 39.

41 «les seigneurs ont puissance d'établir juges et officiers sur leurs terres, mais ils la tiennent du souverain qui la leur a communiquée » LOYSEAU (Discours de l'abus des justices de village) quoted by SEVE, op. cit..

42 SEVE. Op. cit. 
the law. It does not include a new examination of the facts of the case, but only of legal reasoning on the grounds that the law had been violated ${ }^{43}$. If the lower court has misapplied the law or a custom, the king may reverse the decision.

A similar movement to integrate the courts in one legal system can be observed in other countries than France, e.g. in England or in Germany ${ }^{44}$.

Thus, a court decision becomes a third level in the hierarchy of norms: it is valid both from a dynamic point of view (because it has been made by a court acting as delegate of the king, within the limits of its powers, according to the rules of procedure established by law) and from a static point of view because its content must not be contrary to any superior law.

For example, the charter of the Compagnie des Indes occidentales, created by Colbert in 1664, included a provision mandating the appointment of judges. These judges were "bound to decide cases following the laws and ordinances of the realm". On the basis of the same provision officers of the crown were also bound to follow and conform to the custom of Paris that would also rule contracts made by individuals. Neither officers nor individuals were permitted to introduce any new custom, so as to avoid diversity ${ }^{45}$.

When making decisions courts thus appear to be applying a superior rule, statute or custom as prescribed by a statute. Naturally, when a statute is not available, lawyers will cite catholic sources or Roman law, but when there is such a statute, lawyers will use the same kind of syllogistic reasoning that was later theorized by Kant and is still

43 GODIN Xavier, 2010, La procédure de cassation au XVIIIe siècle. Histoire économie \& société,, p 1936

44 BRAND P., La formation du système juridique anglais, 1150-1400, in PADOA-SCHIOPPA, A. (dir.), 2000, J ustice et législation, Paris, PUF, p. 133; and in the same volume HOLMES Clive, Les instruments juridiques du pouvoir et l'Etat dans l'Angleterre du début de l'époque moderne, 315; NEHLSEN VON STRYK K., Centralisation de la justice et formation d'une hiérarchie judiciaire dans l'Etat du début de l'époque moderne : l'exemple de la principauté de Hesse, p.165.

45 Art. 34. "Seront les juges établis en tous lesdits lieux, tenus de juger suivant les loix et ordonnances du royaume ; et les officiers de suivre et se conformer à la coutume de prévôté et vicomté de Paris, suivant laquelle les habitans pourront contracter, sans que l'on y puisse introduire aucune autre coutume, pour éviter la diversité». The charter has been reproduced in PAULIAT Louis, La politique coloniale sous l'Ancien Régime, Paris, Calmann Levy, 1887, p. 221; see FIORAVANTI Marco, Le préjugé de la couleur; François-André Isambert et l'administration de la justice aux Antilles françaises pendant la Restauration, in Cahiers Poitevins d'Histoire du Droit, 2012, forthcoming. 
prevalent today and the techniques of interpretation resemble those that are still being used today for statutes ${ }^{46}$. For example, about the ordinance of 1560 that forbids widows from bequeathing to their second husbands, a lawyer asks whether the prohibition holds if the children born from the first marriage have all died. He answers in the affirmative using three arguments. The first is drawn from the silence of the text of the ordinance: "our prince does not say that such donations or legacies are void". The second is an argument by analogy: donations to the second husband are valid if the widow has no children from her first marriage; if her children have died, she is in a similar situation. And the third argument is drawn from the intention of the lawmaker or the function of the rule: it was made in view of the best interest of the children ${ }^{47}$.

What has been said of custom can be said also of ecclesiastic law. It had been an autonomous source of law, but was integrated into the legal system and became binding not because of the authority of the pope or the council but because of the authority of the king and to the extent that it did not conflict with royal ordinances.

Thus, the Ordinance of Villers-Cotteret 1539 mandates priests to keep registers of baptisms and limits the jurisdiction of ecclesiastic tribunals. The Ordinance of Blois of 1579 regulates in detail the organization of the church, in particular the appointment of bishops, archbishops and abbots and determines the various age when priests can be ordained. On the other hand, in an attempt to limit the number of clandestine marriages, harmful to the preservation of family estates, it regulates marriage ceremonies: priests were under an obligation under very severe penalties to post banns, to keep a register of marriages, to inquire about the parents' consent and to celebrate the marriage only in the presence of four witnesses. A marriage was not valid if these conditions were not satisfied. These rules went further than those laid down by the council of Trent (1565), and a marriage that could have been valid under canon law,

\footnotetext{
46 MACCORMICK,N. \& SUMMERS. R.S (ed), 1991, Interpreting statutes. A comparative Study, Dartmouth, Aldershot, .

${ }^{47}$ CHARONDAS LE CARON, op. cit. p. 218.
} 
which only required consent, could therefore be invalid under the ordinance ${ }^{48}$. More generally, Canon law was applicable only on the basis of the king's explicit or implicit authorization ${ }^{49}$.

Particularly interesting is the case of simony. The church has been condemning the crime of simony (selling or buying spiritual benefits or sacraments for several centuries). The ordinance of Blois mandates bishops to prosecute that crime and gives jurisdiction in part to secular courts instead of ecclesiastic courts to decide on these matters. Thus, as with custom, the decisions of the bishops and the courts, even when they apply canon law, are based indirectly on secular law.

It is easy to see how the king can take advantage of these developments. Not only does he now have a monopoly of the production of general rules, but also he is not forced to produce laws that would go deep into details, something that could be technically difficult or politically challenging because it could encounter resistance. He can now chose between giving reception to previously autonomous sources, such as custom, empowering lower authorities or authorizing discretion in the process of application. As Bernard Guenée rightly notes, legal centralization is not the enemy of decentralization and decentralization was not an obstacle to the construction of the State $^{50}$. Quite the opposite: by accepting the creation of provincial parliaments, the king achieved two results: he established his authority over these parliaments, which exercised a delegated power and applied his laws; he gained political acceptance of his authority by the provinces.

\section{The Creation of a hierarchy of norms from below}

The courts can also contribute to the creation of a hierarchy, which may increase their power, because of the necessary latitude that they will necessary enjoy in the process of adjudication, particularly because they have to interpret the law. A law is but

48 De BOUTARIC, François, 1745, Explication de l'Ordonnance de Blois, Paris; DAUCHY Serge, DEMARS-SION Véronique (ed.), 2005, Les recueils d'arrêts et dictionnaires de jurisprudence (XVIeXVIIIe siècles, Paris, La mémoire du droit, p. 431.

${ }^{49}$ DUCCINI Hélène \& HERMANN Christian, op. cit.; Frédéric MARTIN, op. cit. p. 313.

50 GUENEE B. Espace et État dans la France du bas Moyen Âge, in Annales. Économies, Sociétés, Civilisations. 23e année, N. 4, 1968. p. 744-758 
words on paper. It is not a legal norm until these words are interpreted as having the meaning of a legal norm. Of course, the lawmaker himself gives it precisely that meaning, but, as Kelsen puts it, this is only a "subjective meaning". Its "objective" meaning can only be provided by the legal system as a whole. As is well known, in Kelsen's theory a text or any human act has the objective meaning of a norm when it has been made according to a higher norm. However, in the realist model, the objective meaning is given by the authority who, in the process of application, interprets the text, thus deciding that it has the meaning of a legal norm, and determining its nature, its level in the system and its content ${ }^{51}$. Very often, but not always, that authority is a court. Once the court has thus created the norm and applied it, this norm is the basis for the validity of the lower norm i.e. the court's decision.

As both Kelsen and the realists have argued, interpretation is a function of the will, so that the "authentic" interpreter enjoys wide - some say complete - discretion. When they exercise their power of interpretation, the courts create, manipulate and maintain a hierarchy in two ways.

First, by interpreting a text as having the meaning of a superior norm to be applied in a case, they create that superior norm. One might think that the law's supremacy is lost because of the power of the court to interpret and it was indeed a danger well perceived by lawmakers. Thus, Louis XIV in 1667 expressly prohibited any interpretation and ruled that whenever there was a doubt regarding the meaning of a law, the question was to be referred to $\mathrm{him}^{52}$. He was only reformulating a rule originally in the J ustinian digest, but also part of canon law and expressed by the maxim "ejus est interpretari legem cujus est condere". The same rule was later reproduced in the most

51 TROPER M., 2001, Le droit, la théorie du droit, l'Etat, Paris, PUF p. 69.s.

52 Ordonnance civile de 1667 «: Si dans les jugemens des procès qui seront pendans en nos cours de parlement, et autres nos cours, il survient aucun doute ou difficulté sur l'exécution de quelques articles de nos ordonnances, édits, déclarations et lettres-patentes, nous leur défendons de les interpréter: mais voulons qu'en ce cas elles aient à se retirer"; see ALVAZZI DEL FRATE, Paolo, 2000, L'interpretazione autentica nel XVIII secolo: divieto di interpretatio e riferimento al legislatore nell'illuminismo giuridico. Torino: G. Giappichelli, ; ALVAZ7I DEL FRATE, Paolo, Aux origines du référé législaif : interprétation et jurisprudence dans les cahiers de doléances de 1789, in Revue Historique de droit français et étranger, 2008, n², p. 253-262; DAUCHY, DEMARS-SION (dir) op. cit.. 
important law on the judiciary passed at the beginning of the Revolution ${ }^{53}$. The fear behind the prohibition, one that is shared by lawmakers in many different systems, is that courts could substitute their own preferences to those of the lawmaker, so that they would become the true legislators.

However, it is naturally impossible to apply a text without interpreting it and the courts never had the intention or indeed the capacity to avoid interpreting. However,, contrary to what one might think, the process of interpretation does not reverse the hierarchy. One might argue that the law that is supreme is not the text enacted by the king, but the norm that is the meaning of the text, as determined by the court, to the effect that instead of constructing a hierarchy, the power of interpretation seems to have the opposite effect, since the law is being recreated by the court.

However, the supremacy of the law remains, but we must understand it differently: a hierarchy of norms is not necessarily a relation between norms laid down by different authorities. Such a hierarchy can also obtain between norms created by the same authority whenever the first is used as an argument to justify and assert the validity of the second. This is the real hierarchy behind the apparent official one. It gives the courts a power that is all the greater for being hidden ${ }^{54}$.

The second mode of constructing a hierarchy is by deciding that a text or a practice has the meaning of a legal norm and determining the level at which it is placed in the hierarchy.

One classical example in contemporary French Law is that of the Declaration of the Rights of Man of 1789. After it was enacted, it was not considered as a set of binding legal norms, but rather as a philosophical basis for the constitution or a political agenda. It was not until 1971 that the Constitutional council decided that it was a legal norm, that it was part of the constitution and that it was binding on Parliament (although not on the people voting in a national referendum).

However, Parliaments did something similar in France, starting in the $16^{\text {th }}$ century, making a distinction between rules that the king could amend and those that he

53 The law passed during the Revolution is the act of 16 et 24 august 1790 .

54 DI DONATO F., 2010, La rinascita dello Stato - Dal conflitto magistratura-politica alla civilizzazione istituzionale europea, Bologne, Il Mulino, , con prefazione di Michel Troper. 
could not, and thus attempting to create a new superior level in the hierarchy. In 1586, in a speech addressed to the king, de Harlay, the First President of the Paris Parliament declared: "we have, Sire, two kinds of laws; the former are the laws and ordinances of the kings, the latter are those ordinances of the realm that are immutable and inviolable and by which you ascended the royal throne. Thus, you must observe the laws of the State of the realm that cannot be violated without calling your own power into question"55. The laws that the king could not amend were mostly rules of succession to the throne and the inalienability of the royal domain. They were predominantly customary rules, but some were confirmed by royal ordinances. Yet, the distinction meant that some of these rules were upgraded to a super legislative level with the purpose of allowing Parliaments to exercise a form of judicial review over ordinary legislation by means of a confrontation of royal ordinances to these fundamental laws ${ }^{56}$.

Although the king fought such attempts by Parliament to invalidate his laws, he did acknowledge the principle that there were some laws that he could not amend. Shortly before his death, in 1714, Louis XIV, whose only legitimate heir was the future Louis XV, a fragile four years old, decided to legitimize his bastards and declared that they could ascend the throne, in case there was no legitimate prince. This was clearly a violation of the Salic law, one of the fundamental laws. Immediately after his death the declaration was abrogated not by the courts but by the regent in the form of an edict of the new king, the little Louis XV, by which he proclaimed that "the fundamental laws of the realm please us in the fortunate powerlessness to alienate our crown's domain... we take pride in acknowledging that we are not at liberty to dispose of our crown"57.

Some historians have recently claimed that these immutable rules of the realm were the equivalent of a modern constitution, so that the review by parliaments of the

\footnotetext{
55 In SAINT-BONNET F., SASSIER Y., Histoire des institutions avant 1789, op. cit, p. 276.

56 DI DONATO F., 2003, L'ideologia dei robins nella Francia dei Lumi. Costituzionalismo e assolutismo nell'esperienza politico-istotuzionale della magistratura di antico regime (1715-1788), Napoli, Edizioni Scientifiche Italiane, ; La rinascita dello Stato. Op. cit.

${ }^{57}$ MOUSNIER (Roland), 1980, Les institutions de la France sous la monarchie absolue, Paris, 2 vol, vol. 1. p. 503; HALEVY Ran, La déconstitution de l'Ancien Régime. Le pouvoir constituant comme acte révolutionnaire, in ,Jus Politicum $\mathrm{n}^{\circ} 3$,. http://www.juspoliticum.com/La-deconstitution-de-lAncien.htmls
} 
king's ordinances could be interpreted as prefiguring judicial review 58 . This view misses the important point that a modern constitution expresses the will of a constituent power and is always amendable, while the fundamental laws were for the most part customary and unamendable even by the sovereign. However, the important point is that the courts have created a superior level of norms.

The structuration of the legal system and the hierarchy of norms may explain the emergence of the modern concept of sovereignty.

\section{Sovereignty}

The idea that Sovereignty is an essential character of the modern State is commonly accepted. This classical definition is precisely the reason why those have recently argued that states have lost their sovereignty or that their sovereignty has been limited, qualify this development as the decline of the State ${ }^{59}$. This is also the reason why most historians who defend the view that the State has emerged in the Middle Ages are constrained to claim that the king already exercised sovereignty long before Bodin coined the theory.

They use a variety of arguments. Some rest on words. Most historians agree that the word "sovereignty" only appeared in the $16^{\text {th }}$ century, but some stress that the adjective "sovereign" referring to an authority is more ancient or that, although the substantive "sovereignty" was not in use until the $16^{\text {th }}$ century, other terms such as maiestas, potestas absoluta, summa potestas, imperium conveyed the sale meaning or

\footnotetext{
58 MESTRE J.-L., "L'évocation d'un contrôle de constitutionnalité. ; "Les maximes du droit public français" (1775), in Association française des historiens des idées politiques, Actes du Colloque de Toulouse, 11-12-13 avril 1991, Etat et pouvoir, l'idée européenne; Presses universitaires d'Aix-Marseille, 1992, pp. 21s. ; RENOUX-ZAGAME, M-F., 2003, Du droit de Dieu au droit de l'homme, Paris, PUF, ; DI DONATO F., L'ideologia dei robins op. cit; KRYNEN, Jacques, 2009, L'état de justice : France, XIIIeXXe siècle. Tome 1, L'idéologie de la magistrature ancienne, Paris, Gallimard, ; SAINT BONNET F., Un droit constitutionnel avant le droit constitutionnel ? in Droits 32, 2000, pp. 7-20s

59 Among many others CASSESE S., 2002, La crisi dello stato, Roma-Bari, Laterza, ; VAN CREVELD Martin, 1999, The Rise and Decline of the State, Cambridge University Press, ; FIORAVANTI Maurizio, Sovereignty and Constitution. The European Model in the late nineteenth and the early twentieth century, in CAZ7ANIGA Gian Mario \& Zarka Y.C. (dir.), 2001, Penser la souveraineté à l'époque moderne et contemporaine, Pise - Paris, Edizioni ETS - Vrin, tome II, p. 509 ff; contra : TROPER M, The survival of sovereignty, in Hent KALMO and Quentin SKINNER 2010, Sovereignty in Fragments. The Past, Present, and Future of a Contested Concept, CambridgeCambridge University Press.
} 
at least part of that meaning. Others still maintain that, even if in the language of the Middle Ages there was no term that was the exact equivalent of sovereignty, the type of power that was exercised at the time could nevertheless be rightly described as sovereign. In order to prove that point, they have to rely on a definition of sovereignty that is necessarily anachronistic. In the same way that some of them use Weber's definition of the State when they look for a medieval State, others use a concept of sovereignty posterior to the Middle Ages when they analyze the medieval legal system and most often it is Bodin's. However, when looking at the emergence of the modern State we cannot take for granted that Bodin invented once and for all the modern theory of sovereignty. We need a truly modern theory that can provide us with a metaconcept. Once we have defined that metaconcept, we can then ask whether it fits the concepts that we can find in the Middle Ages, and later in the $16^{\text {th }}$ and $17^{\text {th }}$ centuries .

Before going further, we must stress an important point that could easily be overlooked: sovereignty is a legal theory. It is part of reality only to the extent that theories and language are part of reality, but no more. It follows that for a polity or a man to be sovereign, means that they have certain legal capacities, not that they have real political, economic or military power, so that we cannot falsify the theory that the king was sovereign in the Middle Ages just by showing that he did not exercise effective power over such and such group or such and such part of his kingdom, nor that he was constrained to seek the consent of some other group.

However, as a legal theory, it does not exist only in a world of ideas and the fact that some thinker has developed some elements of a theory of sovereignty at one moment in time is not sufficient for us to say that sovereignty "existed" at that moment. It exists only in so far as arguments from the theory are those that count as valid arguments to justify decisions made by actors in the system.

We can thus identify sovereignty when we find actors using concepts derived from a theory of sovereignty. The modern theory that can provide the necessary metaconcepts is that of Carré de Malberg, who breaks the notion of sovereignty into three concepts.

"In the original sense, the word "sovereignty" refers to the supreme character of the State's power. In a second sense, it refers to the whole range of the powers included 
in the State's authority and it is therefore synonymous with that authority. Thirdly, it is used to characterize the position occupied within the State by the highest organ of the State's authority and in that sense, sovereignty is the same thing as the power of that organ"60.

Carré de Malberg stresses that the French language is poor and contains only one word for these three concepts of sovereignty. The same could be said of English. However, the German language has three words, one for each of these senses. Souveranität corresponds to sovereignty in the first sense, i.e. the supreme character of the State on the international as well as on the domestic level. Staatsgewalt is the power of the State in the second sense. Herrschaft is the power of domination by an organ. Carré de Malberg believed that these distinctions could help us discover the "true nature" of sovereignty ${ }^{61}$. Such a belief may be naive, but the distinction is nevertheless useful to clarify a few traditional puzzling questions.

One of these is whether it is possible to divide sovereignty. On the basis of Carré de Malberg's distinction it is easy to see that sovereignty in the third sense, the quality of the highest organ of the State, is indeed indivisible, because, as soon as one divides it between several organs, none is the highest ${ }^{62}$. On the other hand, if sovereignty in the second sense is the range of powers that can be exercised by the State, it is perfectly divisible. It is even possible to divide them by their subject matters (the power to wage war, to control a currency, to render justice, etc.) as Pufendorf did with the partes potentiales $^{63}$ or by the type of legal acts that are necessary to exercise them (like legislation, execution and adjudication). Separation of powers is precisely a division of sovereignty in this sense.

In the same way these distinctions help to understand why some sentences using the concept of sovereignty, which seem incompatible or contradictory can nevertheless,

60 CARRE DE MALBERG Raymond, 1920, Contribution à la théorie générale de l'Etat; spécialement d'après les données fournies par le droit constitutionnel français, Paris, Sirey, réimpr. CNRS, 1962, nlle édit. Dalloz, 2003, .Vol. I., p. 79.

61 Ibid. p. 86.

62 However, several organs could exercise sovereignty jointly, see below.

63 PUFENDORF, 1706, Le droit de la nature et des gens, traduit du latin par J ean Barbeyrac, Amsterdam, Livre VIII :"Où l'on traite des principales parties de la souveraineté". 
be simultaneously true. Thus, at the time of Carré de Malberg, during the French Third Republic, it was possible to answer the question "who is the sovereign", by any one of three sentences: " the French State is the sovereign", "the French Parliament is the sovereign", and "legislation is a sovereign power". In the first sentence, sovereignty refers to the supreme character of the State's power, which enables it to act on the international level and interfere with other sovereigns, or to dominate the church or any other institution. In the second sentence, sovereignty is a quality of an organ of the State, and in the third sentence it is one of the powers that the State may exercise.

However, Carré de Malberg's distinction does not give sufficient account of some sentences that we find in constitutional and political discourse. Take for example, "the sovereign is the French people" or, "sovereignty belongs to the people"64. Such a sentence obviously does not mean that the French people is the State and effectively acts on an international level, nor that it exercises a power of domination and certainly not that the people alone can really exercise a range of powers. These propositions do not refer to any reality and they are only used to justify other sentences: e.g. in French legal discourse "sovereignty belongs to the people" was used during the Third Republic to justify "Parliament is sovereign" or "the law is sovereign". It meant that Parliament exercised a sovereignty that was not its own, but belonged to the people and was exercised in the name of the people, or that statutes were presumed to express the general will, i.e. the will of the sovereign and were therefore supreme. In this context, when imputed to the people, the word "sovereignty" is thus used in a fourth sense: it refers to the quality of a being in whose name some power, in any one of the first three senses, is exercised. Indeed, the theory of sovereignty generally implies a distinction between the essence and the exercise of sovereignty. Because of the hierarchy of norms, what is imputed to a sovereign is not only legislation or decisions in international affairs, but also every single act, presumed to have been performed in virtue of a delegation. This is why e.g. justice is rendered in European countries "in the name of" the French, Italian or German people as it was before "in the name of the king". To Carré de Malberg's three concepts, we must therefore add a fourth : the doctrine of ${ }^{64}$ Constitution of 1958, art 3. 
sovereignty is a principle of imputation. A sovereign in that fourth sense is the entity presumed to possess the essence of a sovereignty that is exercised by others in its name and thus to be the author, direct or indirect, of every single norm in the system.

Using this distinction between four different concepts of sovereignty, we can see that whereas sovereignty in the Middle Ages is discernible only in two senses of the word, it is only in the $16^{\text {th }}$ century that it exists in the full four senses.

\section{A. The absence of sovereignty in the Middle Ages}

Some of the French historians of the Middle Ages who claim to discover sovereignty in the Middle Ages are not without ideological biases, which may be diverse. One is the wish to escape the influence of German $19^{\text {th }}$ century legal scholarship while insisting on the French origin of the theory and contrast the authoritarian German State with the more "moderate" French State, because the latter was bound by morality or natural law or because the French king reigned with the advice and consent of the barons or the courts, so that "État de droit » might appear to be not only more ancient but also more liberal than the "Rechstaat"65. Obviously, those who follow this path must find a way to explain how sovereignty, which is defined an unbound power, can nevertheless be bound.

Some of these historians contrast such a political system with later ones, which they considered to be truly tyrannical. This attitude is not limited to medieval historians and we can find it in the writings of historians of absolutism. Thus a famous historian of the Ancien Regime, Roland Mousnier, denying that the absolute monarchy was really absolute, wrote that under the reign of Louis XIV, "the rights of subjects, their freedoms, franchises and privileges, were part of a protected sector. All these guaranties were destroyed by the Revolution. The true absolutist governments were those later governments where the will of the lawmaker, the will of the majority becomes the supreme law, without any guaranty for the citizen"66.

65 BARRET-KRIEGEL Blandine, 1986, Les chemins de l'Etat, Paris, Calmann-Lévy.

66 «Les droits des sujets, leurs libertés, franchises et privilèges forment un secteur protégé. Toutes ces garanties furent détruites par la Révolution. Les vrais régimes absolus furent les régimes postérieurs où la volonté du législateur, la volonté de la majorité devint la loi suprême, sans aucune garantie pour les 
These writers implicitly rely on Bodin's theory that the sovereign is bound by natural law and they seem to commit the logical fallacy that if the king was called sovereign in the Middle Ages and was considered to be bound by natural law, then he must have been sovereign in the sense of Bodin.

In reality, the adjective "sovereign" in the Middle Ages applied not only to the king but to any supreme authority who could make a decision in the last instance, like barons or courts and had no superior. As a matter of fact, it is still used in this weak sense in the French language in relation to superior courts like the court of cassation or the Conseil d'État which make final decisions and even in relation to a panel of university professors, which is also called sovereign because the grades given by the panel cannot be reviewed on the merits.

In the late Middle Ages the word "sovereign" had also a stronger meaning; the sovereign exercised Herrschaft or domination. However, nobody claimed at that time that this implied Staatsgewalt or the unlimited power to decide by legislation or otherwise on all human affairs and to be the sole source of law67. Although the king gradually came to exercise powers similar to those of the roman emperor - particularly the power to make general laws and to render justice - he could only legislate on certain matters and he did not have a monopoly of legislation or of judicial power.

As we already have seen, legislation was not entirely an expression of the king's will and human affairs were regulated for the most part not by the king, but by custom, the courts or canon law.

Most important, since there is not one single legal order, all decisions are not imputed in the last instance to the king's will. Indeed most, as in the case of customary rules, cannot be imputed to anyone's will. As Yan Thomas wrote about the roman Republic " there could be no sovereignty - imputation of all decisions to one single center - in a system where the powers of every organ rested on an autonomous

citoyens ». MOUSNIER Roland, 1980, Les institutions de la France sous la monarchie absolue, Paris, 2 vol,, vol. 1, p. 515.

67 QUARITSCH (H.), op. cit. Quaristsch speaks of the "uber die Unmögligkeit 'mitttelaterlicher' Souveränität" p. 34. 
foundation"68. Thus sovereignty in the full sense of the word did not exist until the $16^{\text {th }}$ century.

\section{B. Sovereignty in the modern age}

From the $16^{\text {th }}$ century onwards, sovereignty is much closer to Carré de Malberg's analysis and corresponds to the four concepts. First, as was already the case in the Middle Ages, the king claims to possess a power supreme in the sense that there is no other power above his own, so that neither the pope nor the emperor could produce legislation on temporal matters that would be binding in the realm.

Secondly, also as in the Middle Ages, he was the highest authority within the realm. Thus, it is not surprising that the Latin expressions used for sovereignty are the same as in the medieval period, summa potestas by Grotius or majestas by Bodin. But these terms had once only conveyed the idea of a relative superiority not of an absolute supremacy and did not imply that the bearer of that potestas or majestas had the power to do anything 69 .

What is different from the Middle Ages then is the type and the range of powers that the king can exercise. Now, the terms acquire new meanings and the king's power extends to all human affairs. We have already noted that in the medieval period, royal legislation did not deal with private law, which was left to custom or canon law, but in the $16^{\text {th }}$ century we see some very important laws, like the 1579 ordinance of Blois on marriage and also on some ecclesiastic matters, the 1539 ordinance of Villers-Cotteret mandating priests to register baptisms and also the use of the French language in official acts instead of Latin, or the ordinance of Moulins of 1566 on justice, which also mandates that donations between private persons be registered in the courts or that the towns provide food for the poor. As Loyseau writes "it is difficult to assuredly list the rights of sovereignty, as ancient philosophers have almost not mentioned it, because in

68 THOMAS Yan, L'institution de la majesté, in Revue de Synthèse N ³-4, 1991, pp. 331-386, at p. 385.

69 Ibid. For summa potestas see Van Gelderen Martin, Airstotelians, Monarchomachs and Republicans: Sovereignty and respublica mixta in Dutch and German Political Thought, 1580-1650, in SKINNER Quentin \& VAN GELDEREN, Martin (ed.), 2002, Republicanism and constitutionalism in early modern Europe : Cambridge : Cambridge University Press, p. $195 \mathrm{ff}$. 
their time sovereignties had not been well established"70. It is difficult now not for lack of literature but because you can hardly make a list of elements that extend beyond all limits. After the Revolution, constitution makers will realize that since sovereignty is the power to legislate on all possible matters, a list would be useless and it suffices to devise a procedure to exercise that power. Any possible subject matter falls within the jurisdiction of the lawmaker provided that he regulates it with formal legislation enacted according to the prescribed procedure.

Among the affairs regulated by the king's laws, religion is particularly significant, but every book dealing with sovereignty or public law, starting with Bodin, has long lists of powers that it comprises, organized by subject matters. The novelty of this concept of sovereignty lies precisely in the fact that the sovereign holds- and is indeed defined by the power of intervening in every possible domain ${ }^{71}$, including religion or the subjects' properties.

Finally, the fourth concept of sovereignty, imputation, also appears in the $16^{\text {th }}$ century. Previously, such an idea had been inconceivable previously because of the plurality of legal orders, but now institutions do not rest on separate basis and all possible legal norms are finally either laid down by the king, by an authority explicitly or implicitly delegated by him or tacitly authorized. Imputation is thus simply an expression of the hierarchy of norms.

It is remarkable that the concept of imputation can refer both to the ascription of an attribute or an action to a person and to the relation between two norms. Kelsen clearly shows that it is one and the same relation ${ }^{72}$. The statement that a crime is imputed to a person means that she is legally considered as having committed the crime and that a sanction can be inflicted upon her. Imputation is therefore the relation between crime and sanction. This relation is not a causal one, because it is not

70 «il est malaisé de cotter assurément les droits de souveraineté, pour ce que les anciens philosophes n'ont en presque point parlé à cause que de leur temps les souverainetés n'estoient pas bien nettement établies » (Loyseau Charles (1608), Traité Des Seigneuries, Paris, chap. III, p. 49,

${ }^{71}$ SEVE R. , Le discours juridique dans la première moitié du XVIIème siècle, op. cit.

72 KELSEN (Hans) (1973), Essays in Legal and Moral Philosophy (selected and introduced by Ota Weinberger), Dordrecht-Holland/ Boston - U.S.A., Reidel, chapter VII "Causality and Accounting”, pp. $154 \mathrm{ff}$. 
necessarily the case that when someone has committed a crime she will be punished. It is a relation created by a norm that states that if a crime has been committed then the person who committed it ought to be punished. But more broadly imputation is the relation between the two elements of the norm "if $\mathrm{x}$, then $\mathrm{y}$ ought to be". It is the internal structure of the norm ${ }^{73}$.

It follows that the concept also helps to characterize the structure of the whole legal system, because a higher norm empowering an authority to produce a lower norm can be read "if the authority x makes a decision then that decision is legally valid", e.g. "if a court finds that one of the parties to a contract did not consent, then the court ought to declare the contract void". The relation between the higher and the lower norm is a relation similar to that between crime and sanction and we can say that the lower norm is imputed to the higher and the latter to an even higher norm. In the end, they are all being indirectly imputed to the highest norms and to their author who, not having been empowered by any other superior legal norm must be presumed to be sovereign.

\section{The hierarchy of norms and sovereignty}

Sovereignty thus appears to be a concept that one is bound to encounter whenever there is a hierarchy of norms that are thought of as produced by the will.

It can best be understood by analogy with Kelsen's theory of the Grundnorm. It is well known that for Kelsen the validity of every norm is based in a higher norm, which in turn is based in an even higher one and so on until one reaches the highest norm in the system. Since it is the highest there is no higher norm on which it could be based and yet if it is not valid, it cannot serve as the basis for the validity of the lower norms. This is the reason why we have to assume that the highest norm is valid on the basis of a Grundnorm, which states: "the highest norm is valid". Everybody is of course perfectly aware of the fact that there is no such norm and Kelsen does not pretend that there is.

\footnotetext{
73 “Ce sont deux faits qu'unit l'un à l'autre l'imputation juridique: non pas l'acte créateur de droit et la conduite conforme au droit, mais le fait que l'ordre juridique érige en condition et le fait qu'il érige en conséquence" (KELSEN Hans, 1962, Théorie pure du droit, Paris, Dalloz, trad. fse de la 2è édit. allde. par Ch. Eisenmann, réédit. LGDJ, 1999, p. 144.
} 
On the contrary, he calls it a fiction. But this fiction is necessary because without it we could not treat any norm as valid.

However, Kelsen's theory rests on ontology of norms, conceived as ideal entities that are not and cannot be produced by the will, because they belong to the sphere of "ought" whereas the will is a fact and belongs to the sphere of "is". The validity of a norm can only be based on another norm, not to on a fact. When an authority wills a rule, that rule is not valid because of the will, but only because the higher norm that empowered that authority, has prescribed that if the authority expresses the will to create a rule, then the rule is valid and binding. Thus Kelsen was able to avoid imputing the Grundnorm to a will.

But, the legal system in $16^{\text {th }}$ century France rests on a very different ontology, inherited from Roman law, that law is an expression of the will ${ }^{74}$. In that case, every decision or norm in the system is valid because it has been willed by an authority delegated or authorized by a legislative rule, but this rule must also express the will of some entity, a will that has not been authorized by any earthly authority ${ }^{75}$. J ust as with the Grundnorm, we must therefore assume that this entity (whether the people, the king or an aristocracy) possesses an inherent quality that enables it to produce law without having been authorized. This quality is sovereignty.

It is therefore not surprising that lawyers easily made that assumption. Sovereignty has not been invented by Bodin or by anybody else, just as Kelsen did not invent the Grundnorm, no more than he could have discovered it in positive law. He only claimed that it was an assumption or presupposition of any lawyer who purports to treat something as valid law and that he, Kelsen, just brought this hidden assumption to consciousness.

However, if Bodin did not invent sovereignty, he did not describe positive law either and there is no clear correspondence between his conception of legislation and

\footnotetext{
${ }^{74}$ ALCHOURRON and BULYGIN call it the expressive as opposed to the hyletic ontology (1979, Sobre la Existencia de Ias Normas Juridicas, Valencia-Venezuela ; 'The Expressive Conception of Norms', in R. HILPINEN (ed.), 1981, New Studies in Deontic Logic, Dordrecht. .

75 MARTIN F., JEAN BODIN ET LES FORMES, in 2009, Etudes d'histoire du droit offerts à Albert Rigaudière, Paris, Economica.
} 
the practices of the $16^{\text {th }}$ century ${ }^{76}$. And he did not describe actual processes of argumentation of his time. Rather, his was an interpretive theory in Dworkin's sense: what he did was discover the best possible argument to justify the power of the entity to whom all the norms in the system are imputed, the argument that was assumed by the whole legal process and bring it to consciousness. The argument was that this entity was sovereign and that he possessed a godlike quality.

The argument that sovereignty implied the monopoly of power had been discovered by the king before Bodin's Republic. For instance, in the édit de Moulins 1566, he justified a prohibition to any other authority to raise taxes by asserting that « to do otherwise would undertake on our authority and majesty $\gg 77$.

It was overwhelming used after the publication of his book, both by the king or his counselors or his subjects urging him to adopt new legislation. E.g. the Estates General of 1614, in order to render the king and the kingdom independent from the church, declare "that since the king is recognized as sovereign in his State and holds his crown from God alone, no power on earth, whether spiritual or temporal, has any right on his kingdom and can deprive of them the sacred persons of our kings, nor dispense their subjects from their faith and obligation they owe him"78.

Kings expressly claimed the godlike quality. Already during the celebrations for the wedding of Arthur Tudor and Catherine of Aragon in 1501, a figure on one of the pageants, dressed as a god, had been made to look like the King Henry VII ${ }^{79}$ and J ames I, who had read Bodin, in the famous speech addressed to Parliament in 1609 insisted that « Kings are not only God's lieutenants upon earth, and sit upon God's throne, but even by God himself they are called gods », an idea also expressed later by Bossuet preaching before the court «you are gods" 80 .

76 Ibid.

77 art. 25.

78 cited by COURTINE J-F., L'héritage scolastique dans la problématique théologico-poiltique de l'âge classique, in ROBINET André, L'Etat baroque op. cit. p. $91 \mathrm{ff}$.

79 PENN Thomas 2011, Winter King. The Dawn of Tudor England, Penguin, p. 60.

80 "Vous êtes des dieux encore que vous mourriez, et votre autorité ne meurt pas.. l'homme meurt, il est vrai, mais le roi, disons nous, ne meurt jamais. L'image de Dieu est immortelle » (BOSSUET, Troisième sermon pour le Dimanche des Rameaux, prêché devant le roi. Sur les devoirs des rois, in Euvres complètes, Paris 1825, vol. 4, p. 64). 
One of the strong points of Bodin's theory is that it works just as well whether the sovereignty bearing entity is a king or the people or a mere abstraction, whether sovereignty derives from god's delegation, as it does in the case of the king, or is based on the nature of the sovereign as in the case of the people. This is because the king's godlike quality is not related to his personal virtue but only to the nature of his power. It is not his godlike quality that makes him a sovereign but sovereignty that makes him a god.

This is the reason why the theory of sovereignty, in spite of the references to the divine right of kings, is essentially secular. The sovereign king is not the person who happens to be on the throne it is the institution. One of the most certain signs of the secularizing role of the theory of sovereignty is the change in the function of the coronation. Already in the $13^{\mathrm{TH}}$ century, Philip III had become king after his father's death and was crowned only a year later. Thus it was neither the oath that he took on that occasion nor the anointment that made him king. Nevertheless it was still the anointment with the oil from the "sainte ampoule", on the model of the sacrament of bishops, which during the Middle Ages gave him his charismatic quality. Only after having been anointed was he able to perform miracles and heal the sick suffering from "ecrouelles", a form of tuberculosis affecting the skin or scrofula, simply by touching them.

However, at the end of the period, he did not need to claim this charismatic quality anymore and the formula that he used when touching the sick changed. Instead of saying, "the king touches you, God heals you", Louis XV said, "the king touches you, may God heal you"81.

That there is a necessity because of the hierarchy of norms to use the argument of sovereignty as a principle of imputation is shown clearly in the $18^{\text {th }}$ century struggles between the king and the Parlements. The Parlements claimed the right to refuse the registration of the King's ordinances when they conflicted with their interpretation of the fundamental laws of the realm. As we have seen, this was an attempt to extend the

81 MOUSNIER, R. (1979). The institutions of France under the absolute monarchy, 1598-1789. Chicago, University of Chicago Press, p. 655. 
hierarchy by creating a new level above the king. Since they exercised wide discretion in the interpretation of fundamental laws, this was a means to participate in the exercise of legislative power, without admitting it. However, even if this interference in the legislative power was disguised as judicial review, the idea that the king's power could be checked was difficult to reconcile with the doctrine that the king was sovereign. The most efficient way to attempt such reconciliation was to claim that since the Parlements were delegated by the sovereign, when they exercised a check on the king, they still acted in the name of the sovereign ${ }^{82}$. When they refused the registration of a law, they didn't oppose the king's will, because such a law only expressed the king's apparent will, the will of the individual who happens to be on the throne, not the real will of the king as an institution. The real will was thus expressed by the Parlement. The unity of the system was thus preserved and this solution carries two further benefits. It provided a possible answer to the question “Why can't the king, if he is sovereign, change the fundamental laws of the realm?" The answer could be "the king as an individual can't, but the king as an institution definitely could, but, thanks to the Parlements, he is wise enough not do it". On the other hand, it provides a solution to the problem of checks to the power of the sovereign. The difficulty lies in the idea that if a sovereign that is checked is not a sovereign. The solution is in replacing the idea of external checks, such as those which were found in various institutions like the church, the "corps intermédiaires" or the courts, by internal checks that form an integral part of the sovereign. Sovereignty thus remains unlimited, but each of its components is limited. This type of arrangement is the core principle of constitutional government.

\section{Conclusion}

The thesis that the State and in particular its main constitutive element, sovereignty, emerges as a consequence of the hierarchy of norms faces several possible objections. Two are closely linked : firstly, we have not explained in that way the formidable development of the King's power, which results from many social, political, religious or economic factors and secondly we could not explain why the hierarchy of

${ }^{82}$ See the works of Francesco Di Donato mentioned above. 
norms grew in France and not - or not the same degree - in other parts of Europe, why it has produced an absolute monarchy in France, but not in England. The answer is that the thesis does not pretend to describe the actual or effective organization of power, but only the type of argumentation that characterizes the State. This answer should come as no surprise. When we speak of States in international law and when we describe them as sovereign, we call "State" any entity, China or the United States as well as Monaco or Andorra, that fits the definition, regardless of their size, strength or actual capacity to act independently. The same is true of the hierarchy of norms in the $16^{\text {th }}$ and $17^{\text {th }}$ century. The King may face resistance from other institutions. He might even fail completely to impose his will. The fact remains that he claims that courts have been empowered by him, that they are his courts, that they should apply his laws, that he can overrule their decisions or that marriages are to be celebrated according to his rules. The hierarchy of norms is a type of argument that one makes about the reason why a rule is valid or binding and these arguments are being used by various authorities. They can be more or less successful but the simple fact that they are being used is evidence for the existence of a legal system. Similarly, the existence of a hierarchy of norms leads to the argument that there is a sovereign, whether the claim is made by the sovereign himself or by another authority. The argument may be thought persuasive or not. The fact remains that it is being made, unlike what happened in previous political systems, where different kind of arguments drawn from canon law, custom or feudal relations were used by those who wished to impose their authority. The power that is being exercised by means of arguments that there is a hierarchy of norms and a sovereign can thus be identified a State.

However one could agree that there may be some causal relation between the development of a hierarchy of norms and the emergence of a concept of sovereignty and still deny that the former has produced the latter. One could argue that the opposite is true and that it is the sovereign who produces the hierarchy of norms, e.g. when the king orders the writing of customs, makes rules regarding marriages or mandates the application of ordinances by the courts. Naturally, he needs might in order to impose his will, but the objection is based on a confusion between the king's political might and sovereignty and takes too seriously the idea that the king "is" sovereign. Sovereignty is 
not a quality like physical strength or intelligence or prestige that the king possesses and that he can use to do certain things. It is only an argument that he is constrained to invent in order to justify what he does, e.g. producing a hierarchy of norms. The State as political form emerges precisely when the type of rules and of relations between rules are justified by the concept of sovereignty. 